\title{
LINGUISTIC AND EXTRA-LINGUISTIC ASPECTS OF FORMING NEW ZEALAND ENGLISH VOCABULARY
}

\author{
Anna Bekeeva ${ }^{1 *}$, Elena Notina ${ }^{2}$ \\ ${ }^{1}$ Assoc. Prof., Peoples' Friendship University of Russia (RUDN University), RUSSIA, \\ bekeeva_ar@rudn.university \\ ${ }^{2}$ Prof. Dr., Peoples' Friendship University of Russia (RUDN University), RUSSIA, \\ notina_ea@rudn.university \\ ${ }^{*}$ Corresponding Author
}

\begin{abstract}
The article considers extra-linguistic and linguistic aspects of forming New Zealand English vocabulary. We have highlighted the reasons of language changes. New Zealand English contains Maori words related to Maori cultural traditions, many of which have become part of New Zealand culture, as well as to the flora and fauna of New Zealand, particularly for endemic species, along with place names. Maori loan words are the most outstanding feature of the New Zealand English vocabulary. The paper expresses the view that the formation of the New Zealand English vocabulary was influenced by several extralinguistic factors, primarily: historical; cultural-historical; territorial; socio-economic and socio-political. The choice of language units in New Zealand English on a synchronous cross-section depends on such extralinguistic factors as: the age and belonging to a generation; the social affiliation; the place of residence; the level of education and upbringing; the scope of use of the English language. The current revitalization of Maori language and culture has had an important influence on New Zealand English. Maori is endangered and since the 1980s has been the subject of extensive revitalisation initiatives. It is worth noting that the official status of Maori gave all New Zealanders the opportunity to reflect on their country's bicultural identity. Most of the common Maori names for trees, birds and fish were borrowed in the first half of the 19th century, and words like kauri and totara (trees), tui and weka (birds), tarakihi (fish), pipi (shellfish), katipo (spider) are now basic items to all New Zealanders. The authors conclude the vocabulary is dominated not by new lexical units (neologisms), but by lexical and semantic variants of common English units, or rather their figurative uses. This circumstance is associated with the activation of certain layers of vocabulary that reflect relevant phenomena for society.
\end{abstract}

Keywords: Maori, extra-linguistic, linguistic, New Zealand English, New Zealand.

\section{INTRODUCTION}

New Zealand consists of the South and North Islands in the southwestern Pacific Ocean. The indigenous people of the country are Maori, who called New Zealand "Aotearoa» (the land of the long white clouds). The Maori are descendants of the Polynesians The Tangata Whenua or «The people of the land», the first settlers of the South and North Islands, who arrived in New Zealand around 1150-1200 AD. Local Maori traditions say that the first discoveries of the islands of New Zealand belong to the Polynesian navigators Kupe and Toi. The specificity of New Zealand is not only linguistic, cultural, natural, geographical, but also historical originality. The historical aspect is one of the main prerequisites for the birth of the English language in New Zealand. The emergence of the English language in New Zealand referred to 1769, when James Cook reached the coast of New Zealand and claimed it for the British Crown.

T. Deverson points out that the proper nouns Maori itself and its complementary Pakeha (only recently capitalised) also date from the early 19th century. Maori derives from an adjective meaning 'ordinary', 'usual', 
while Pakeha, whose derivation is disputed, was the term applied to the extra-ordinary immigrant white race (Deverson, 1991, p. 19). During the years of colonization, the word "Pakeha» denoted loyal subjects of the mother country in New Zealand. Pakeha has word-forming capabilities, for example, Pakeha culture 'culture of European settlers', Pakeha aggression 'aggression of settlers', Pakeha customs 'customs of settlers'. Currently, this word is used to refer to Europeans. The Maori called the sailors of the British ship «tangata tipua», which meant 'a stranger'. A word "New Zealanden» was used to refer to the indigenous inhabitants the Maori. Today, the word «New Zealanden» is used with respect to both the Maori and English-speaking ethnic group in New Zealand. According to the concept of British colonial policy, New Zealand had favourable climatic conditions for European settlements and necessary resources to strengthen the economic power of Britain (Gordon, Hay, Maclagan, Cambell, Sudbury, Trudgill, 2004, p.33).

\section{METHODOLOGY}

When a linguistic form from one language is used in another language, such words are known as borrowings or loan words (Crystal, 2003, p. 56). A significant contribution to the activation of borrowings from the Maori language was made by the British captain James Cook. He explored not only the New Zealand Islands, but also the indigenous language. The traveller's diary was devoted to a description of his acquaintance with the Maori people. The causes of language changes in contact between different cultures are divided into extralinguistic and linguistic. A striking example of the importance of extralinguistic factors in the development of the lexical level was the contacts between English and Maori. T. Deverson claims that most of the words from Maori life denoted specifically Maori objects and customs, though a few came to be used in Pakeha contexts as well, such as whare (hut) and mana (reputation, prestige) and colloquialisms like kai (food), puku (stomach), taihoa (wait), puckeroo (broken, Maori pakaru), half-pie (imperfect, Maori pai 'good'). Many other cultural terms were recorded in the 1800s but as the Maori and their language went into decline these had only limited currency. The Maori resurgence of the past ten to fifteen years has, however, revitalised this whole area of borrowing into New Zealand English, with many other loans being revived and others being used in English for the first time (Deverson, 1991, p. 19).

The reasons for language changes are of a public nature. They are rooted in the historical, economic, political, social and cultural development. Familiarity with the life and culture of the population led to the need for an environmental nomination and borrowing at the initial stage of colonization. In the J. Cook's records first recorded words were from the Maori language, such as: pa - a protective village, patu - a short club which Maori used in hand-to-hand combat, haka - a ceremonial dance or challenge in Maori culture, kumara - a sweet potato. J. Cook and his crew kept detailed and accurate records of what they saw: unusual birds, fish, trees and plants. It is worth noting that these words were first borrowed by the J. Cook's expedition members (Bekeeva, Notina, Bykova, Uliumdzhieva, 2020, p.1242). The need for naming things and concepts is the main reason for borrowing lexemes. Borrowings are only a certain product of the contact of language communities.

In close connection with the historical is the cultural-historical aspect. The significance of the cultural and historical aspect is that the British colonialists launched a process of political, economic, cultural integration, inter-ethnic consolidation and the construction of new cities throughout the country. The desire of the settlers to maintain English language traditions, orientation to British ideals and values can also be traced in the names of some New Zealand cities. The cities of Wellington, New Plymouth, Nelson, Otago and Canterbury were created. The relationship with Great Britain had become an important part of the cultural selfdetermination of the New Zealand society. It was the image of England that had always served as a source of effective economic achievement and literacy. The orientation of New Zealanders towards British ideals and values provided for their desire for social, cultural and political progress. The first settlers called Great Britain as Mother Britain, home, homeland, mother country. In colonial times, New Zealand was known as God's own country, the social laboratory of the world, where an equal classless egalitarian society flourished, Great Britain of the Southern hemisphere, the South Seas, the Wonderland of the Pacific, the Britain of the South, the Paradise of the South Sea, the country of gold diggers (Digger land).

The change in socio-economic conditions and the growth of national consciousness reflected in the formation of a new socio-cultural community and, accordingly, the New Zealand national literary norm. In the speech of New Zealanders, expressions appeared that characterize the ingenuity and resourcefulness of the first settlers, for example, number eight wire 'wire for installing wire fences'. This word is used as a core in the phrases: number eight solution 'an effective decision-making', number eight philosophy 'philosophical campaign to life'. Another example of ingenuity is bach 'a small house built from improvised means'. Currently, this word is used in two main meanings: one of them is 'a bachelor lifestyle'; 'live independently'. Another meaning of the word bach is 'a cottage on the shore' (for a weekend holiday). 


\section{RESULTS}

New Zealand's loyalty to the mother country was expressed by active participation in World War I and World War II. 100, 000 New Zealanders fought in World War I. In 1914, the Australian and New Zealand Army Corps were formed. 17, 000 New Zealand soldiers were killed in the fighting, 41, 000 soldiers were injured, and 9,000 New Zealanders died after the war due to the pandemic. More than 194,000 New Zealanders took a direct part in World War II (King, 1981, p. 265).

New Zealand soldiers were considered strong, brave and modest without the slightest pretence and selfpraise. During these years, New Zealanders called themselves Fernleaves (fern leaves), Enzedders (initial letters NZ + ending - er), Diggers (gold diggers). In 1940, the Government established the celebration of the centenary of the Treaty of Waitangi of 1840 to promote national identity.

It should be noted that the socio-economic aspect had a great impact on the formation of New Zealand English. New Zealand's population is $0.1 \%$ of the world's population, with the country's economy producing about $0.3 \%$ of the world's output. Compared to other countries in the world, New Zealand has a developed economy, characterized by flexibility, openness and high competitiveness. New Zealand is the world's largest food exporter. The main exports from New Zealand are milk powder, butter and cheese, as well as meat and edible offal. The largest export market is Australia, which accounts for almost a quarter of all exports, which is twice the value of exports to China, the second largest export market after Australia.

P. Warren suggests that a number of New Zealand English terms have their origin in Australia: muster (to round up sheep), station (for a large farm), maimai (a duckshooter's hide; originally a makeshift shelter, from aboriginal mia-mia). Tall poppy originated in Australia as a negatively loaded reference to someone who stood out from the crowd (e.g. by being particularly bright or successful). It has been adopted and adapted in New Zealand, giving tall poppyitis, tall poppy pruning, etc., as well as homegrown equivalents like tall ponga 'the ponga is a native tree fern' (Warren, 2012, 92).

In 1839-1840s New Zealand was of great interest to entrepreneurs in the United States, the Netherlands and France in terms of investing capital and exploiting economic resources. Foreign capital made a significant contribution to the development of the national economy, the construction of several enterprises in the timber processing, whaling and mining industries. A significant role in the economy of New Zealand was played by the mining of gold and silver in Otago in 1861 and Westland - 1865. The Gold Rush had a significant impact on the rate of population growth, economic development and food potential of the country. This period was marked by the expansion of trade and economic ties with England, Australia, France and the United States, which played a huge role in the rise of economy and well-being of the population. Gold mining contributed to the rapid development of New Zealand's lands and remote territories, as well as the functioning of language formations (Malahovskij, 1981, p. 53).

Changes at the lexical level were expressed in semantic shifts related to the needs of nominating new or already existing objects and phenomena. Most of the language units of the general English lexical fund associated with the mining industry were used without changes, some of the lexical units were reinterpreted in New Zealand English. The word fossick 'to look for something' has undergone a narrowing of meaning and is used only in the mining industry in the meaning of 'to look for gold'. The following examples of mining terms are crib 'light snack', digger 'gold digger', colour 'gold sand', reef 'gold mine', nugget 'gold bar' (Orsman, 1997, p. 89).

At the end of the 19th century, ironic nicknames of the British appeared in New Zealand English, for example, a new chum 'a newly arrived immigrant'; homey 'a native Briton who immigrated to New Zealand'. The word pommie 'an Englishman' with a pejorative connotation was borrowed from Australian English. By 1920 it had become common and is used as a core in the phrases pommie bashing subjecting the British to harsh and unfair criticism', pommie accent 'speech of the British, especially from the Midlands or with a southern British accent', Pommie-land 'Great Britain', pommie bastard 'insult, abuse'. During World War II, New Zealanders referred to British soldiers by the disparaging word pongo 'a soldier' or pongolian (the adjective is formed by merging the morphemes pongo + Mongolian) in the sense of 'a resident of Great Britain'.

Obtaining the status of the Dominion in 1907, an effective state language policy aimed at developing and strengthening its national and cultural characteristics, a high number of English-speaking people born in New Zealand, the development of their own media contributed to the formation and consolidation of the national literary norm and the growth of its prestige. In 1890, the New Zealand Native Association was established. On their initiative, the magazines "Zealand» (1889) and «New Zealand with Illustrations» (1899) were published, as well as several poems and novels where ideologists emphasized national values and ideals, 
ethnic nationalism of New Zealand.

\section{CONCLUSION}

In 1947, New Zealand was proclaimed a parliamentary monarchy of the Commonwealth. The Parliament of New Zealand adopted the Statute of Westminster in 1931. The country gained independence from Great Britain. In 1952, Elizabeth II was proclaimed the Queen of New Zealand. During that time, the English language of New Zealand had acquired its own specific features. New Zealand English has gradually evolved and developed under the influences of other languages and varieties. Today, New Zealand English can certainly be described as a distinctive variety of English.

From colonial times until the mid-XX century New Zealanders used the concepts of home, Motherland Britain. The expression to go home meant 'to visit or return to the UK' in New Zealand English. The phrase a home boat meant 'a ship that sailed between Great Britain and New Zealand'. England had played a huge role in New Zealand's foreign trade for a long time. The weakening of traditional ties occurred with the entry of the United Kingdom into the European Economic Community. New Zealand was forced to look for new prospects for the development of foreign trade on its own. This trend contributed to the formation of the foundations of national independence and cultural self-determination of the country. Foreign trade is of great importance to New Zealand. The traditional economic relations between New Zealand and the United Kingdom have been replaced by extensive ties with many countries around the world.

The UK is New Zealand's main trade and financial partner and traditional investor. Ever since colonization, the British have viewed New Zealand as a guaranteed market for their manufactured goods. In 1881, New Zealand imported more than $90 \%$ of manufactured goods from Great Britain. Lexical units related to the sphere of agriculture, household use, natural and geographical environment phenomena had become common in New Zealand English. Let's look at the following examples: fly cemeteries 'cookies covered with dried fruit', a lemon squeezer 'a soldier's hat', blushing bride 'pudding covered with raspberry jam', chateau sheep 'New Zealand wine', cop shop 'police station', jandals 'sandals', gas guzzler 'transport consuming a large amount of gasoline', Rob's mob 'R. Muldoon supporters', think big 'a number of R. Muldoon's major government projects in the 1970s, aimed at developing natural resources, six o'clock swill 'closing New Zealand public bars at $6 \mathrm{pm}$ '. The sense of belonging to the British Empire faded with the weakening of its power as a world empire after World War II. In 1984, New Zealand declared the status of an independent anti-nuclear country, establishing a ban on the entry of any ships with nuclear weapons.

We have come to the conclusion that the formation of the New Zealand English vocabulary was largely influenced by extralinguistic aspects, primarily: historical; cultural-historical; territorial; socio-economic and socio-political. The choice of language units in New Zealand English on a synchronous cross-section depends on such extralinguistic factors as: the age and belonging to a generation; the social affiliation; the place of residence; the level of education and upbringing; the scope of use of the English language. Changes in the economic and social life of New Zealand brought to life a lot of new phenomena, concepts, objects, which required the corresponding nomination. Linguistic aspects associated with internal trends in language development contribute to the appearance of borrowed vocabulary in the language. It is worth noting the uniqueness of the language contact situation between Maori and New Zealand English. The penetration of Maori words and their adaptation in New Zealand English is most often provoked by the need to nominate, name new phenomena and objects, as well as the need to clarify the corresponding existing concept. Since each language is different in its universality, so the set of linguistic reasons for the appearance of foreign language vocabulary depends on the specific language. The linguistic aspects of the vocabulary replenishment include forming neologisms with the help of existing lexical and word-forming means; borrowing elements of vernacular, professional and social jargon, individual lexical units from the Maori language; semantic derivation of already existing words. The vocabulary is dominated not by new lexical units (neologisms), but by lexical and semantic variants of common English units, or rather their figurative uses. This circumstance is associated with the activation of certain layers of vocabulary that reflect relevant phenomena for society.

\section{ACKNOWLEDGEMENTS}

The paper has been supported by the RUDN University Strategic Academic Leadership Program. 


\section{REFERENCE LIST}

Bekeeva, A., Notina, E., Bykova, I., Uliumdzhieva, V. (2020). Linguistic and extra-linguistic reasons of Maori borrowings in New Zealand English. 7th International Conference on Education and Social Sciences. Abstracts \& Proceedings. Istanbul: Ocerint Publishing, p.1241-1244.

Crystal, D. (2003). A Dictionary of Linguistics and Phonetics, Fifth Edition. Maldon, MA: Blackwell Publishing, $508 \mathrm{p}$.

Deverson, T. (1991). New Zealand English lexis: the Maori dimension. English Today, vol. 7, issue 2, April, p. $18-25$.

Gordon, E., Hay, J., Maclagan, M., Cambell, L., Sudbury, M., Trudgill, P. (2004). New Zealand English. Its origin and evolution. Cambridge: Cambridge university press, $370 \mathrm{p}$.

King, M. (1981). New Zealanders at war. Auckland: Heinemann, 282 p.

Malahovskij, K.V. Istorija Novoj Zelandii [History of New Zealand]. (1981). Moscow: Nauka. 236 p.

Orsman, H. (1997). The Dictionary of New Zealand English: a dictionary of New Zealandisms on historical principles. Auckland: Oxford University Press, $982 \mathrm{p}$.

Warren, P. (2012). Origins and development of New Zealand English. International Journal of Language Translation and Intercultural Communication, vol. 1, issue 1, p. 87-102. 